\title{
Evaluation of rock slope stability for a touristic coastal area near Kusadasi, Aydin (Turkey)
}

\author{
Yavuz Kaya $^{1} \cdot$ Tamer Topal $^{1}$
}

Received: 7 May 2014/Accepted: 27 April 2015/Published online: 9 May 2015

(C) Springer-Verlag Berlin Heidelberg 2015

\begin{abstract}
The study area, which will be open to tourism in Kusadasi (Aydin), has steep and high cliffs on the Aegean coast in Turkey. Flysch is the main lithological unit and consists of alternating sandstone-claystone-marl sequences. Some sliding and rockfall problems have occurred in the area in the past, so potential geological hazards need to be investigated to ensure the safety of tourists. The aim of this study is to mitigate geological hazards by recommending engineering solutions, which will ensure the continuation of the nature-friendly appearance of the slopes. To accomplish these tasks, a geological survey was performed. It involved gathering information on rock discontinuities by means of scan-line surveys and collection of rock samples. Furthermore, in situ and laboratory tests were also carried out. The data collected from the field and laboratory test results were used to perform slope stability and rockfall (2-D and 3-D) analyses for different slope conditions along 43 profiles. Based on the analyses, rockfall was found to be the main slope instability problem in the study area. Under the light of these studies, rock removal, drainage, greening (vegetation), filling of caverns, protective wall building and erosion prevention are offered as remedial measures.
\end{abstract}

Keywords Flysch $\cdot$ Rockfall $\cdot$ Slope Stability $\cdot$ Kusadasi · Turkey

Tamer Topal

topal@metu.edu.tr

1 Department of Geological Engineering, Middle East Technical University, 06800 Ankara, Turkey

\section{Introduction}

Kusadasi is a touristic coastal town in the Aydin province of Turkey. A coastal area located about $5 \mathrm{~km}$ south of Kusadasi is now under rehabilitation and will be open for tourism in the next few years. However, this area is seriously affected by landslide and rockfall problems where steep and high cliffs (Fig. 1) near the coast pose a great danger to future tourists. Some sliding and rockfall problems have already been observed in the past. These geological hazards need to be investigated and remedial measures which keep the nature-friendly appearance of the slopes should be taken in preparing the area for touristic use. The study area covers $0.24 \mathrm{~km}^{2}$ and has a flat morphology in general but it has steep cliffs on the coast especially at the western part of the region (Fig. 1). Access to the study area is from the Kusadasi-Söke highway in all seasons.

A number of studies related to sliding and rockfall problems exist in the literature (Pfeiffer and Bowen 1989; Turner and Schuster 1996; Guzzetti et al. 2002; Crosta and Agliardi 2003; Schweigl et al. 2003; Wyllie and Mah 2004; Dorren et al. 2004, 2005; Frattini et al. 2008; Choi et al. 2009; Paronuzzi 2009; Tunusluoglu and Zorlu 2009; Binal and Ercanoglu 2010; Volkwein et al. 2011; Ramírez-Herrera et al. 2012; Tanarro and Munoz 2012; Alejano et al. 2013; Fityus et al. 2013; Singh et al. 2013; Shi et al. 2013; Youssef et al. 2015).

The aim of this study is to mitigate geological hazards by suggesting remedial measures which maintain the nature-friendly appearances of the slopes. Slope stability and rockfall (2-D and 3-D) analyses were carried out to design mitigation measures. In this study, methodologies adopted by Kentli and Topal (2004), Öztekin et al. (2006), and Topal et al. $(2007,2012)$ are considered. They mainly 
Fig. 1 General view of the study area with the steep cliffs near the coast

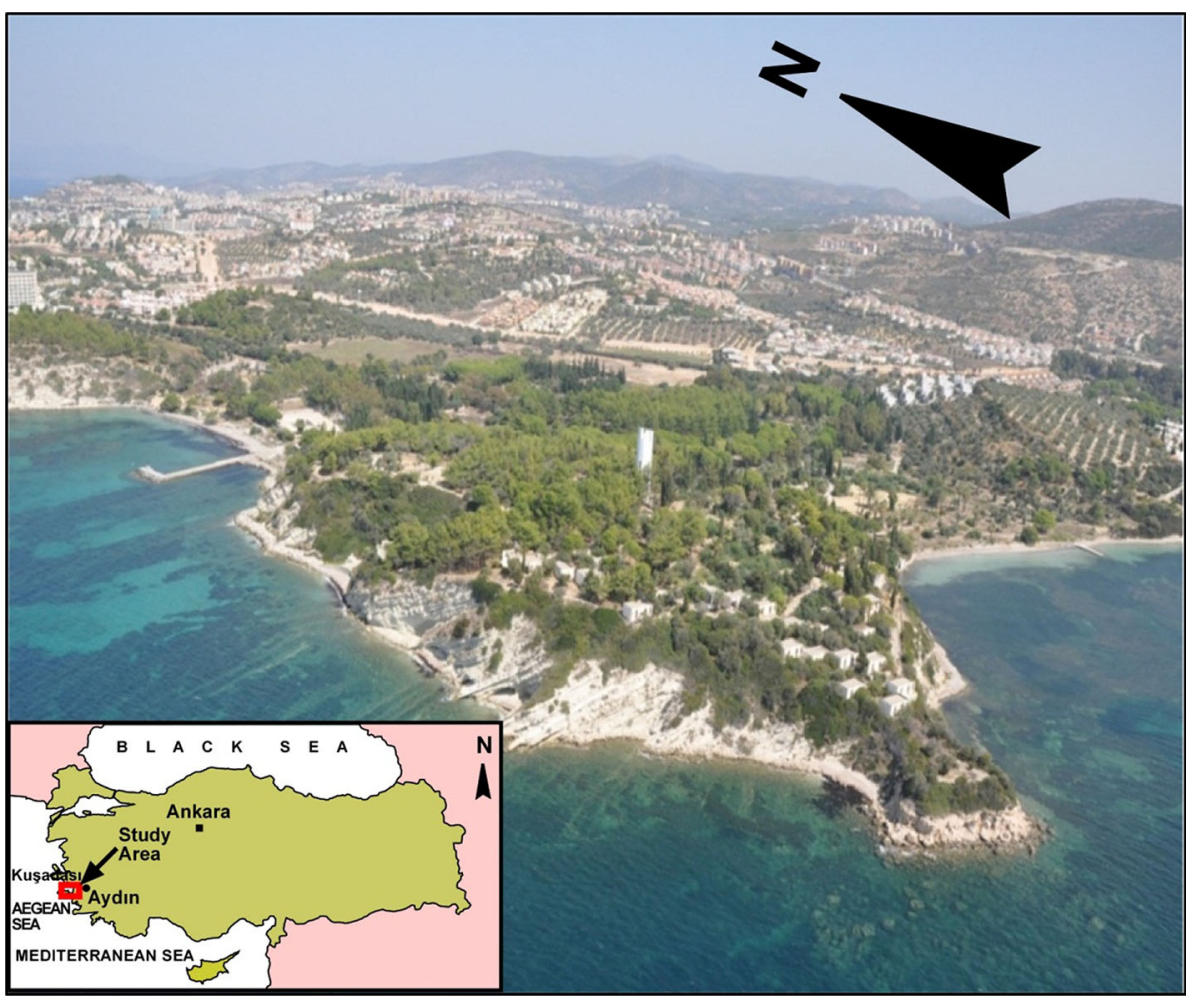

include field and laboratory studies, followed by stability analyses and field checking of the findings.

A typical Mediterranean climate is dominant in the study area. It is hot and dry in summers but mild and rainy in winters. According to meteorological data (DMI 2012), the highest temperature observed in the region is $44.6{ }^{\circ} \mathrm{C}$ in July and the lowest temperature is $-6.0^{\circ} \mathrm{C}$ in January. The annual amount of precipitation is $618.0 \mathrm{~kg} / \mathrm{m}^{2}$. The study area is a green field compared to its immediate surroundings. The area has scrub-type vegetation. Additionally, there are different tree species like black pine, stone pine, olive, eucalyptus, phoenix, palm, calabrian pine, black cypress, pepper and locust.

\section{Methods and materials}

To assess the slope instability problems and take possible mitigation measures, the investigation started by gathering available documents, maps, and other geological studies of the area. Then, detailed scan-line surveys all around the coast were performed. During this study, Schmidt rebound measurements were also carried out with an L-type hammer according to ISRM (1981) from different levels of rocks outcropping in the field. Many block samples were taken for the laboratory tests including unit weight, effective porosity, water absorption, point load strength and direct shear tests along the rock discontinuity surfaces. Geological hazards like slides and rockfalls were investigated in detail. Because the literature gives different values for the coefficient of restitution, which is one of the most important parameters used in rockfall analyses, in situ rockfall tests were carried out by throwing a total of 66 rock blocks along 2 different routes. Kinematic, slope stability and rockfall (2-D and 3-D) analyses for 43 profiles were then carried out for three different slope configurations with the original slope, an inclined slope and a benched slope. The accuracy of the model was further verified by comparing the results derived from the 2-D and 3-D rockfall analyses. Finally, considering all the collected data, remedial measures that would incorporate the naturefriendly appearances of the slopes were suggested as ways to solve the geological problems.

\section{Geology}

The study area is located in the western part of the Büyük Menderes Graben. The Menderes Massif metamorphics comprise the basement of the study area (Yllmazer et al. 1994). Various geological units crop out in this region (Fig. 2). These are schist (upper Paleozoic), marble (middle Triassic-Cretaceous), meta-flysch (upper Cretaceous) and continental carbonates including flysch material (middle-upper Miocene) from older to younger. However, the main unit present in the study area is the flysch material. It is gray, light brown, thin to thick bedded, and moderately weathered. It contains alternation of weak 
Fig. 2 The geological map of the study area and its close 2002) vicinity (simplified from MTA

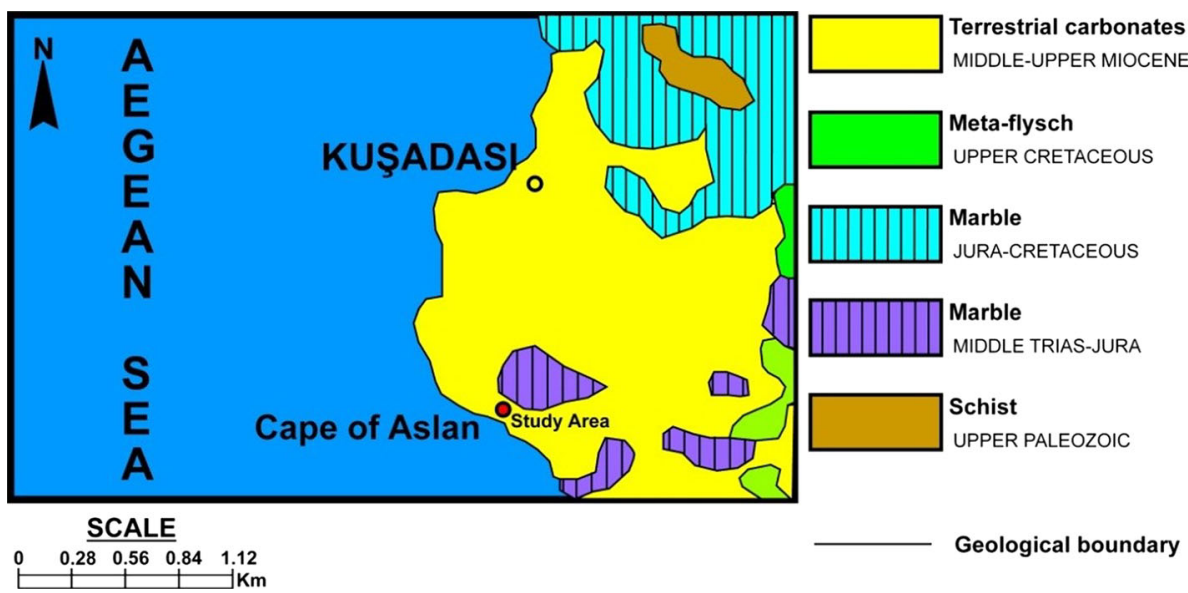

sandstone-claystone-marl. The study area is located in the first-degree seismic zone of Turkey where there is a $90 \%$ probability of expected peak horizontal ground acceleration values that exceed $0.4 g$ occurring within 50 years, according to the Earthquake Zoning Map of Turkey (GDDA 1996).

\section{Field and laboratory studies}

Data collection was performed by means of field and laboratory studies. In the field, soil and rocks were investigated in terms of their engineering geological properties. Data on discontinuities were collected according to Priest (1993) by means of a scan-line survey along 10 profiles. Schmidt rebound hardness measurements were taken from various locations and field rockfall tests with 66 block samples were performed along two different profiles to assess the coefficient of restitution. Samples were also collected for laboratory studies (Fig. 3).

The rocks in the study area are generally gray, light brown, thin to thick bedded and moderately weathered. They consist of an alternation of sandstone-claystone-marl. The most common discontinuity is the bedding plane. Additionally, joints have developed, mainly in two different orientations (Fig. 4). The changes observed in the major discontinuity sets are related to the deformation of the layers.

The thickness of the layers (beds) ranges from 1 to $50 \mathrm{~cm}$. The layers are continuous and their surfaces are generally rough. The kinematic analyses carried out according to Wyllie and Mah (2004) reveal that except in the second, fourth, and fifth locations, no failure is expected in the study area. In the second location (Fig. 5), sliding-type (plane failure) movements and erosion could be seen, while in the fourth and fifth locations wedge failure is expected. Because the dimension of the blocks causing the wedge failure is very small, the failure is expected to be manifest in rockfall mode (Fig. 6). A typical

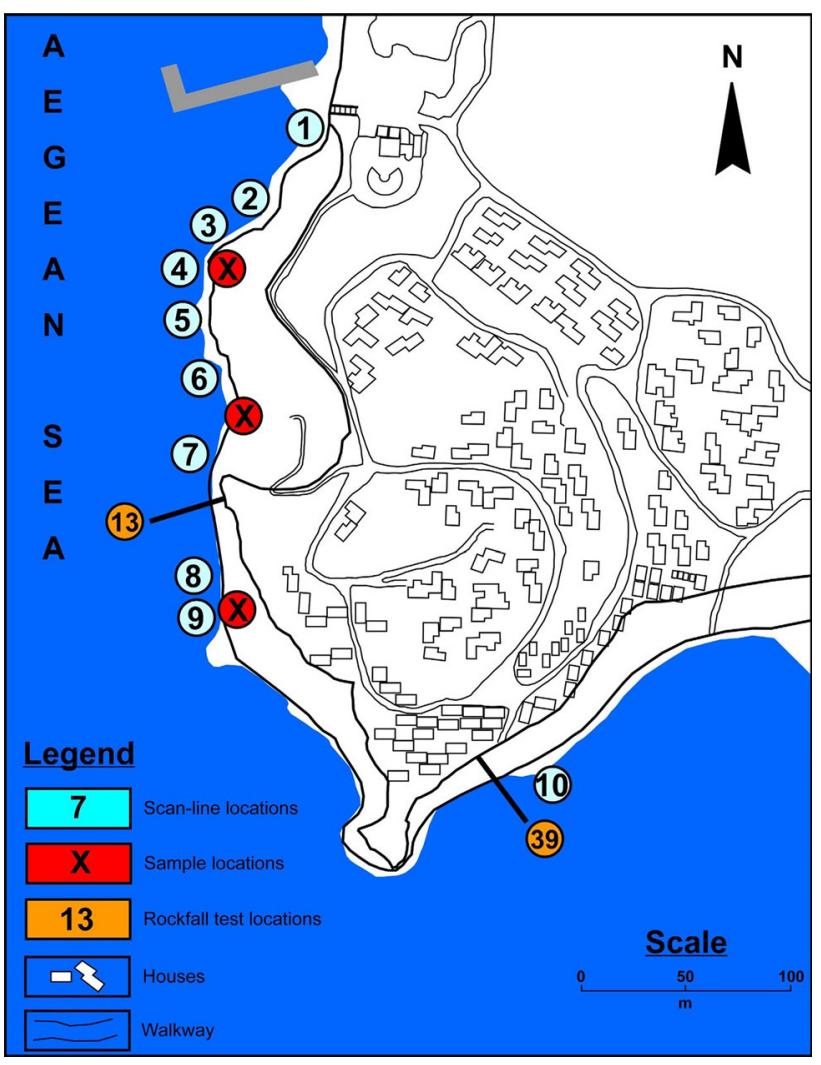

Fig. 3 The scan-line, sample and rockfall test locations in the study area

kinematic analysis for the 4th location is presented in Fig. 7. Groundwater is not encountered in the area. Oxidation marks on the joint surfaces can be seen occasionally in the field. The average Schmidt rebound value of the unit is found to be 42 .

In the laboratory, unit weight, effective porosity, water absorption and point load strength tests were performed on ten samples taken from the field according to ISRM (1981) and ISRM (1985). According to the tests performed on the samples (Table 1), the dry and saturated unit weights are 
Fig. 4 Stereographic projection of the major discontinuity sets in the study area

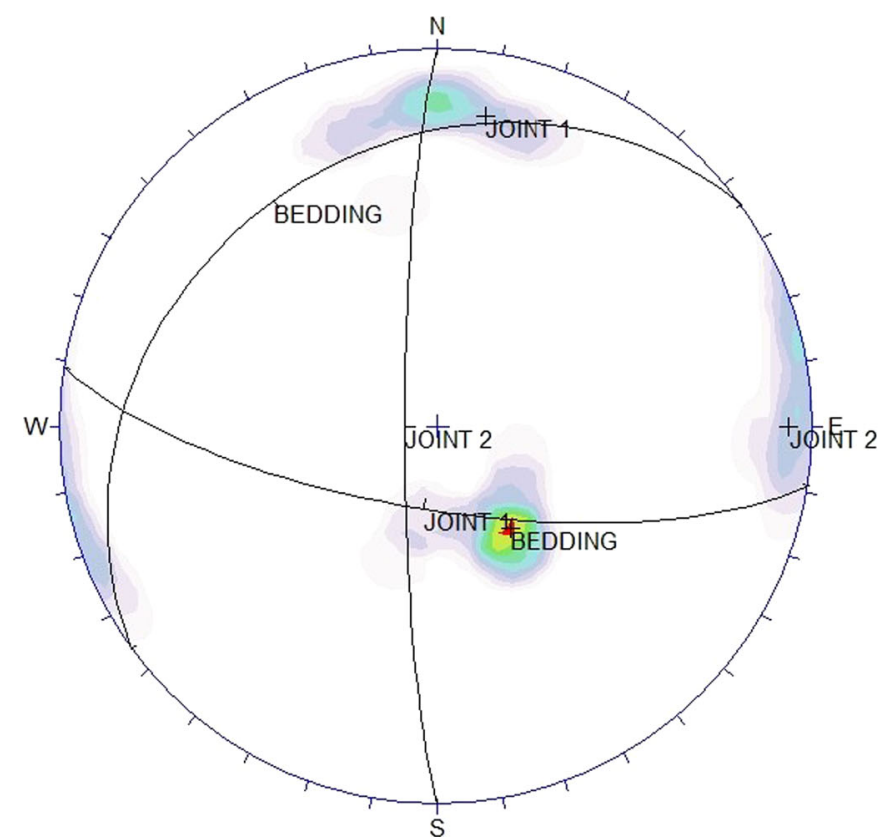

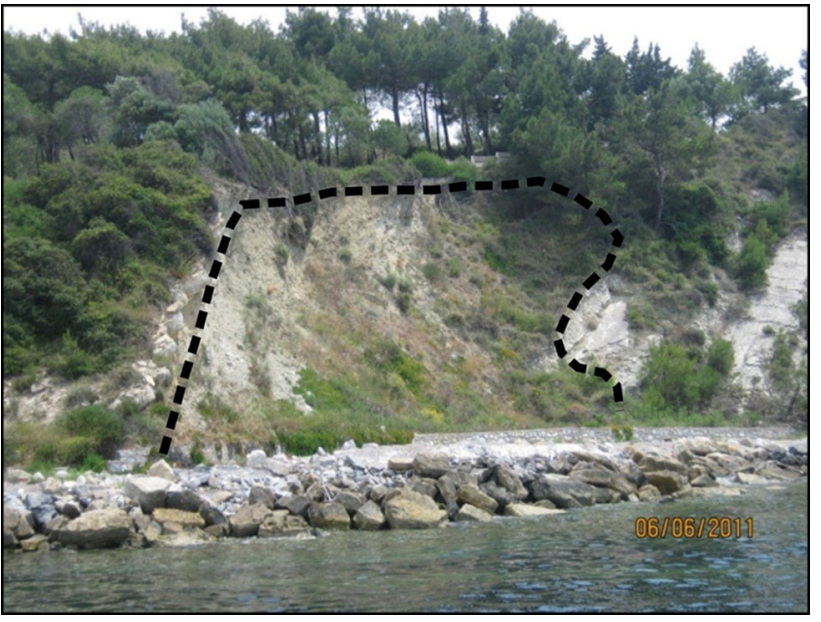

Fig. 5 Very weak sandy siltstone unit

23.60 and $24.48 \mathrm{kN} / \mathrm{m}^{3}$, respectively. Effective porosity and water absorption values are 9.01 and $3.89 \%$, respectively. The average point load strength index $\left(\mathrm{Is}_{50}\right)$ value is found to be $6.06 \mathrm{MPa}$. The sampling could not be performed in the claystone because it is very weak. The flysch material tested has a moderate unit weight and porosity according to Anon (1979).

\section{Slope stability and rockfall analyses}

\section{Rock mass stability analyses}

Circular rock mass failure analyses were carried out along 43 profiles due to the weak and highly jointed nature of the

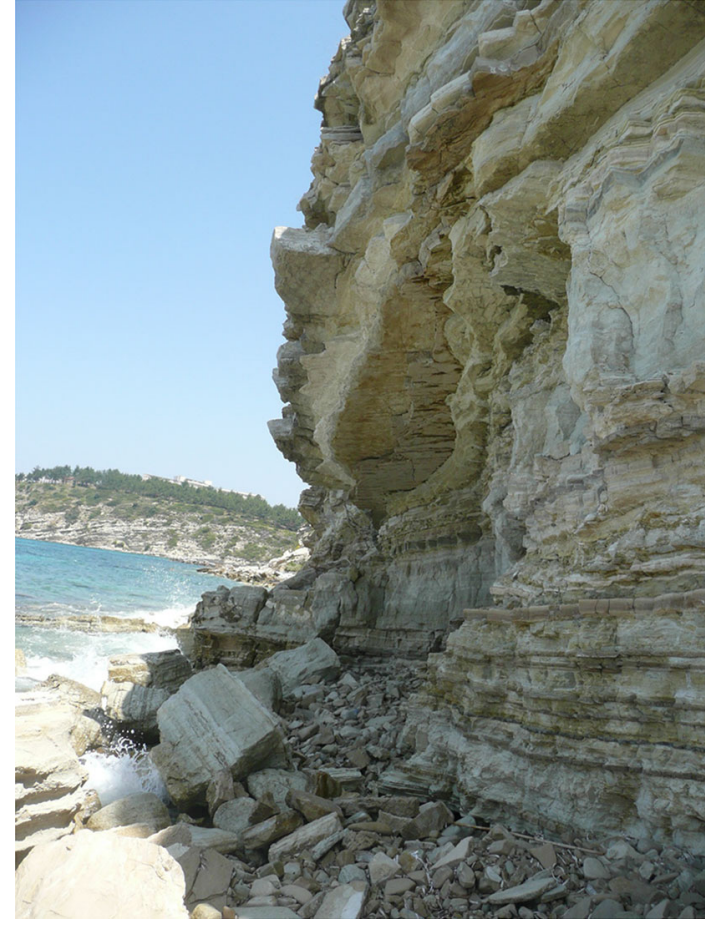

Fig. 6 Photograph showing fallen rocks at the coast

rocks at the coast. The required rock mass shear strength parameters for the limit equilibrium analyses were obtained for these 43 profiles (Fig. 8) by using RocLab 1 software (Rocscience 2011). Because of the blocky structure and very poor surface conditions of the area, the geological strength index (GSI) value (Hoek 2007) was defined as 33. The uniaxial compressive strength value was obtained by 
Fig. 7 A typical kinematic analysis for the 4th profile

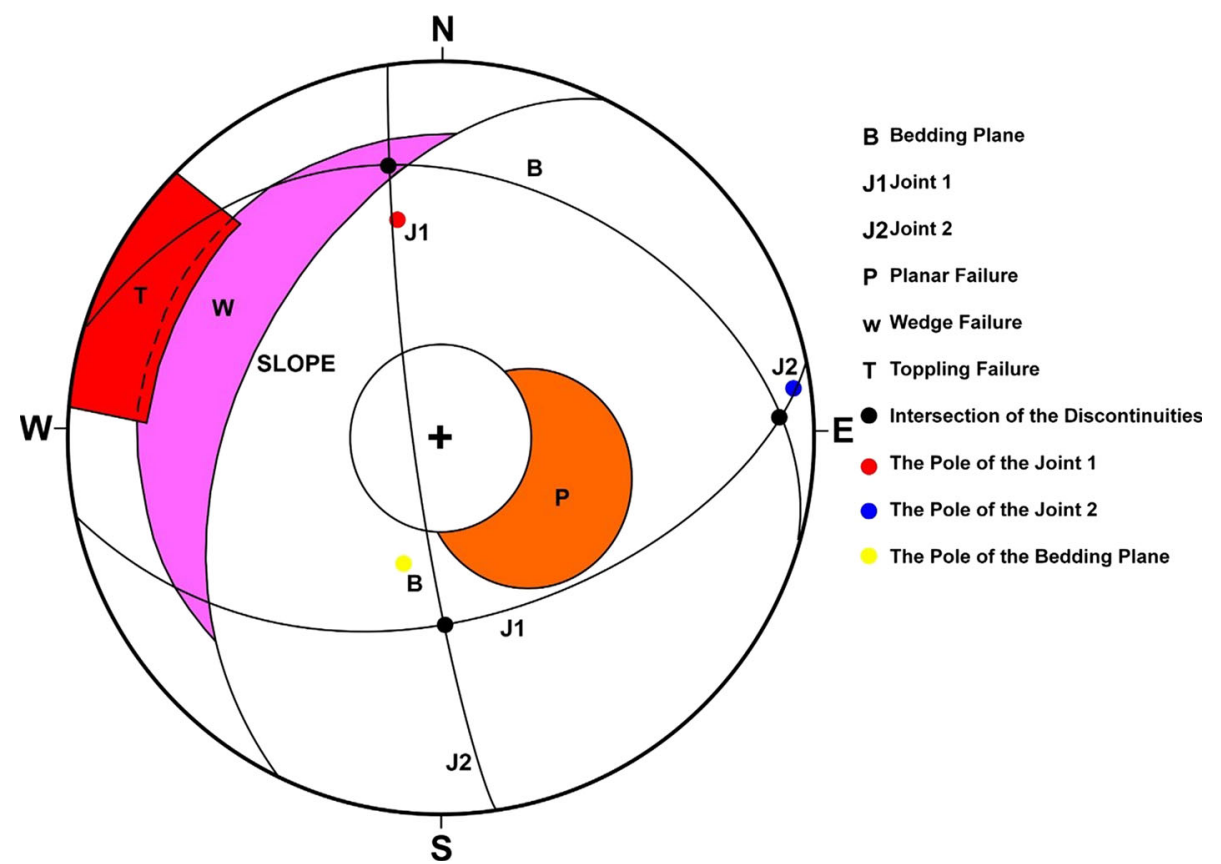

Table 1 Laboratory results of the samples taken from the field

\begin{tabular}{llc}
\hline Tests performed & $\begin{array}{l}\text { Number } \\
\text { of samples }\end{array}$ & $\begin{array}{l}\text { Average } \\
\text { value }\end{array}$ \\
\hline Unit weight-dry $\left(\mathrm{kN} / \mathrm{m}^{3}\right)$ & 10 & 23.60 \\
Unit weight-saturated $\left(\mathrm{kN} / \mathrm{m}^{3}\right)$ & 10 & 24.48 \\
Point load strength $(\mathrm{MPa})$ & 10 & 6.06 \\
Effective porosity $(\%)$ & 10 & 9.01 \\
Water absorption by weight $(\%)$ & 10 & 3.89 \\
\hline
\end{tabular}

correlating the average Schmidt hammer hardness and unit weight values. A uniaxial compressive strength of $(\sigma)=35 \mathrm{MPa}$, an intact rock parameter of $(\mathrm{mi})=5$ and a disturbance factor of $(D)=0.7$ were used as input values recommended by Hoek (2007). The rock mass shear strength parameters ( $c$ and $\phi$ ) were assessed by considering the height of every profile.

The shear strength values obtained for highly jointed rock mass were used in slide 5.1 software (Rocscience 2004a). Limit equilibrium analyses were performed separately for three different conditions at every profile (original slope, inclined slope and inclined with one-bench slope). The rock mass was divided into 30 slices and analyzed using the simplified Bishop method (Bishop 1955). A maximum horizontal ground acceleration value of $0.15 \mathrm{~g}$ was considered for the pseudostatic analysis because the study is located in the first-degree earthquake zone of Turkey. Since groundwater was not encountered in the area, the analyses were performed in dry conditions. However, the saturated unit weight value was used to represent the conditions after a rainy period. A typical

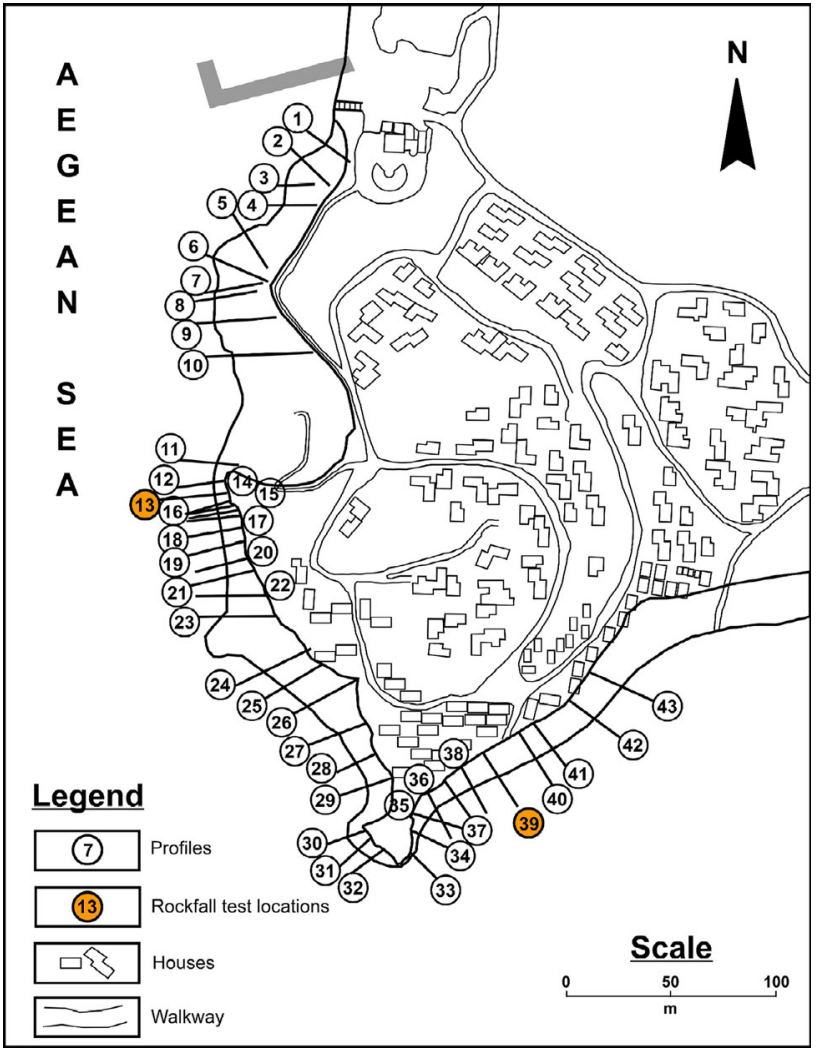

Fig. 8 The profiles where rock mass failure and rockfall analyses are performed

example of limit equilibrium analysis for the 39th profile of the original slope is given in Fig. 9. The factors of safety (Abramson et al. 2002; Duncan et al. 2014) values for all 


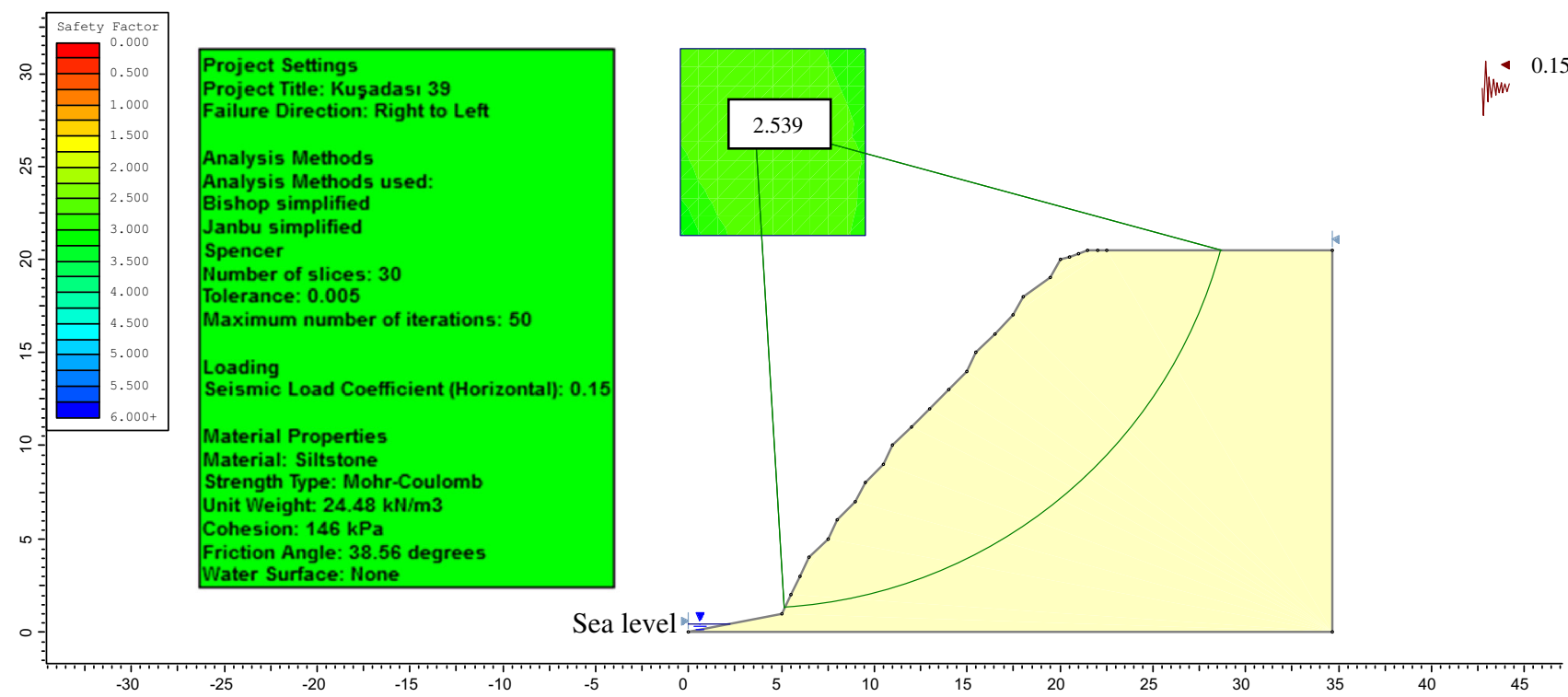

Fig. 9 The result of limit equilibrium analysis for the 39th profile of the original slope

slope types are much higher than 1.5 for all three slope conditions, and circular mass failures are therefore not expected in the cliffs of the study area.

\section{Rockfall analyses}

Rockfall can be described as the rapid movement down a slope of one or a few boulders (Varnes 1978). The rockfall may be formed because of jointing, weathering, freezethaw, the effects of water, earthquakes, or tree roots (Chen et al. 1994; Wasowski and Gaudio 2000; Marzorati et al. 2002; Dorren 2003; Topal et al. 2007; Krautblatter and Moser 2009; Tunusluoglu and Zorlu 2009; Wick et al. 2010; Binal and Ercanoglu 2010). Rockfall threatens humans and can cause significant damage to structures (Topal et al. 2012). For land use planning in rockfall-prone areas, the causes of rockfall events and remedial measures should be considered (Raetzo et al. 2002; Agliardi and Crosta 2003; Corominas et al. 2005; Jaboyedoff et al. 2005; Straub and Schubert 2008; Fell et al. 2008; Agliardi et al. 2009; Wang et al. 2014). The dynamic processes of a rockfall event may be free-fall, bouncing or rolling, depending on the geometrical features and mechanical properties (friction, roughness, rolling resistance, restitution characteristics, etc.) of the slope and rock blocks (Ritchie 1963; Agliardi and Crosta 2003; Alejano et al. 2010; Ansari et al. 2014). As the profile changes, two or more of the rockfall modes may also be observed, depending on the different dynamic processes. Additionally, initial velocity, weight and shape as well as the fragmentation of the blocks and the properties of the slope-forming material may control the rockfall event (Giani 1992; Azzoni et al. 1995; Dorren 2003).
In this study, both 2-D and 3-D rockfall analyses were carried out following the procedures described by Turner and Schuster (2012) and Wyllie (2015). To perform the 2-D rockfall analyses, the dimensions of the blocks prone to fall were defined by analyzing the dimensions and positions of the fallen blocks and using the scan-line survey data performed at ten locations in the field. 66 rock representative blocks were made to fall along profiles 13 and 39 (Fig. 8) to define the normal and tangential coefficient of restitutions $\left(R_{\mathrm{n}}\right.$ and $R_{\mathrm{t}}$ ) quantifying velocity changes during impact (Wyllie 2015). RocFall 4.0 software was used for the 2-D rockfall analyses. It is a rockfall simulation program with lump mass formulation for the prediction of rockfall behavior on slopes and the design of rockfall barriers. First, slope profile is created. Then, material properties such as normal and tangential coefficient of restitution, friction angle, slope roughness are defined. After selecting seeder location, initial velocity, mass and angular velocity are given. End point, bounce height, kinetic energy, and velocity can be calculated along the profile (Rocscience $2004 \mathrm{~b})$. The $R_{\mathrm{n}}$ and $R_{\mathrm{t}}$ values were found to be $0.28 \pm 0.06$ and $0.72 \pm 0.13$, respectively, for profile 13 (Fig. 10) using back analysis. For profile $39, R_{\mathrm{n}}$ and $R_{\mathrm{t}}$ values were $0.30 \pm 0.13$ and $0.64 \pm 0.24$, respectively (Fig. 10). The 2 -D rockfall analyses were carried out along 43 profiles (Fig. 8) to define the rockfall end point. Because of the different material properties observed at the site, the $R_{\mathrm{n}}$ and $R_{\mathrm{t}}$ values obtained from profile 13 were used for the profiles between 1 and 17, and the $R_{\mathrm{n}}$ and $R_{\mathrm{t}}$ values obtained from profile 39 were used for the profiles between 18 and 43 . The other parameters used in the analyses are given in Table 2. The 2-D rockfall analyses were performed (Fig. 11) separately along the 43 profiles for the original slope, 
Profile 13 - Rn Rt

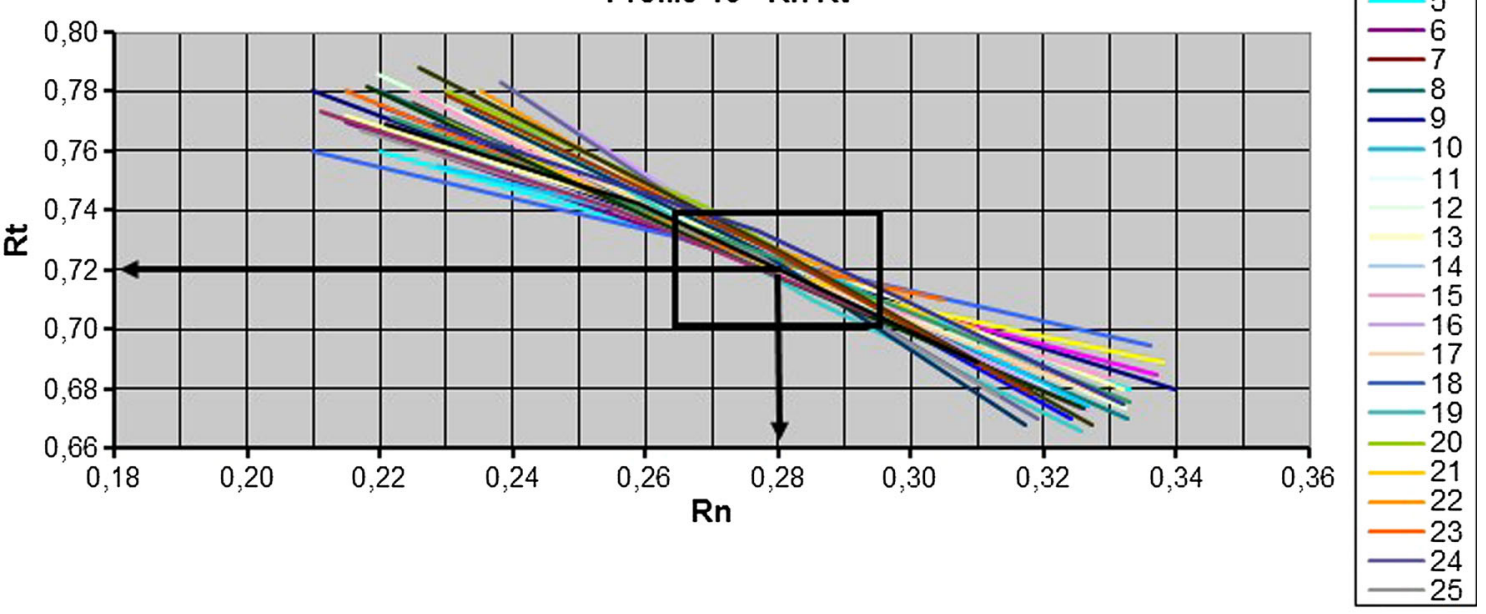

Profile 39 - Rn Rt

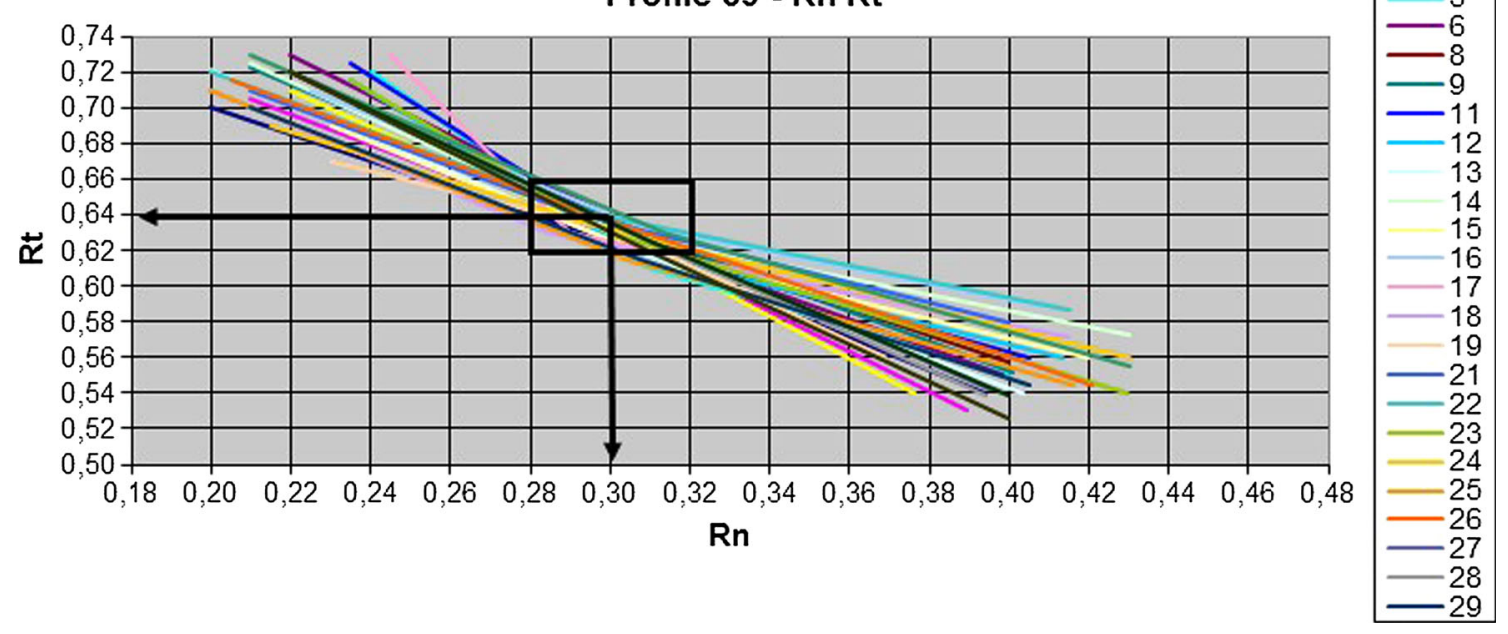

Fig. 10 The back analysis result for the profiles 13 and 39

Table 2 The parameters used in the 2-D rockfall analyses

\begin{tabular}{ll}
\hline Parameter & Value \\
\hline Total number of fallen blocks & 1000 \\
Friction angle $\left(^{\circ}\right)$ & 20 \\
Slope roughness & 0 \\
Block weight $(\mathrm{kg})$ & 88 \\
Initial velocity $(\mathrm{m} / \mathrm{s})$ & 1.5 \\
Minimum velocity cut-off $(\mathrm{m} / \mathrm{s})$ & 0.1 \\
Number of throws & 1000 \\
Sampling interval & 100 \\
\hline
\end{tabular}

inclined slope and benched slope. When the rocks were made to fall from the original slope, some of them went as far as the sea. This also applies to the inclined, and inclined with one-bench slopes. When the rockfall end points were considered for all slope conditions (Fig. 12), it became clear that the rockfall blocks act in falling mode and stop at a shorter distance in the original slope conditions. For the original slope, these blocks describe a falling mode style. On the other hand, rolling and bouncing movements are dominant in the other two slope conditions (inclined and benched slopes) and the end points imply a larger run-out. These slopes may therefore pose a danger for people near 

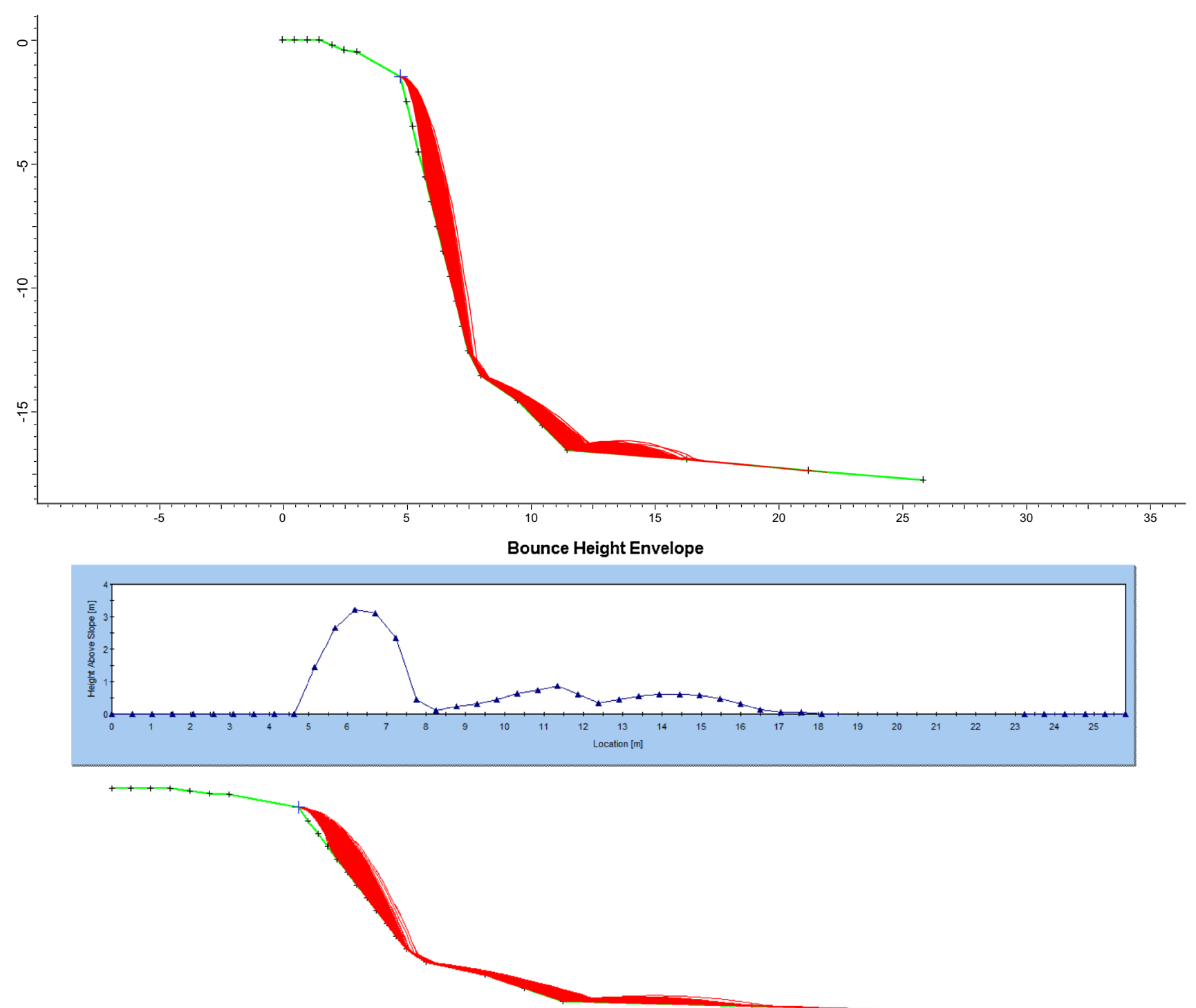

Horizontal Location of Rock End-points
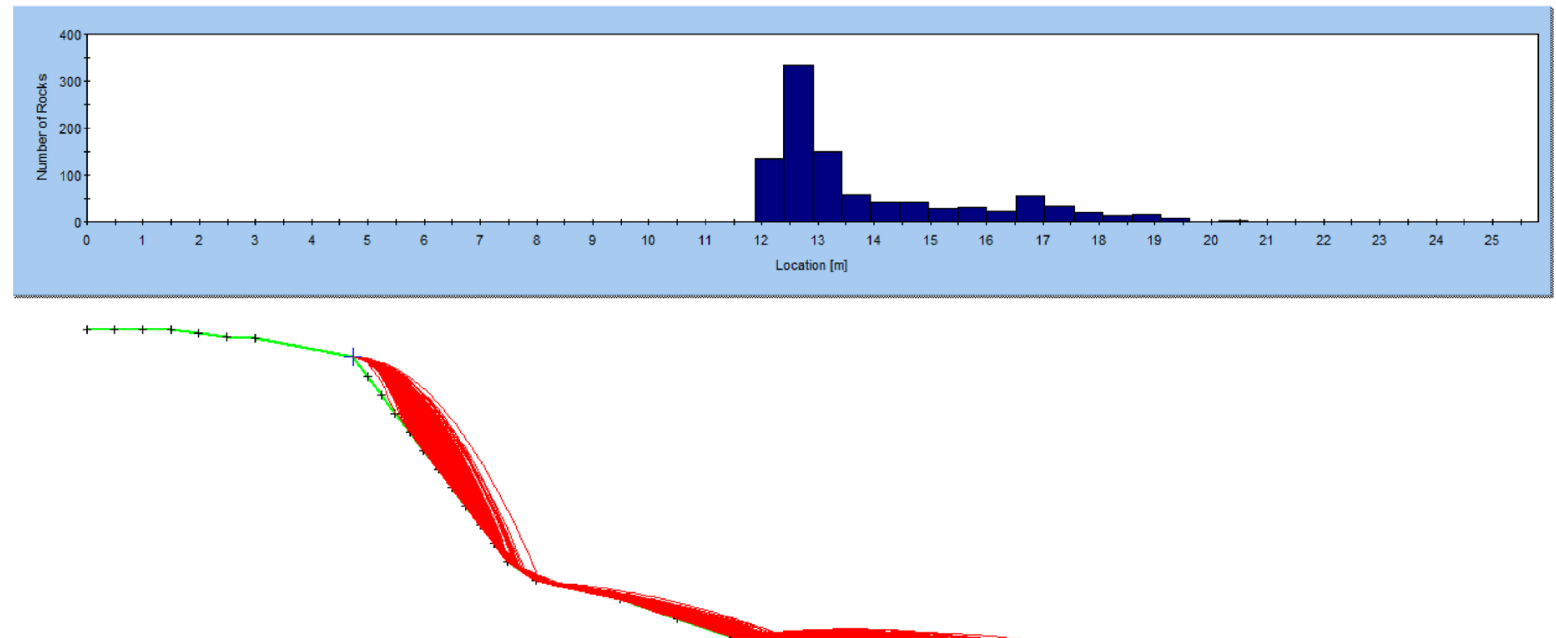
4Fig. 11 A typical 2-D rockfall analysis for the original slope of the 13th profile

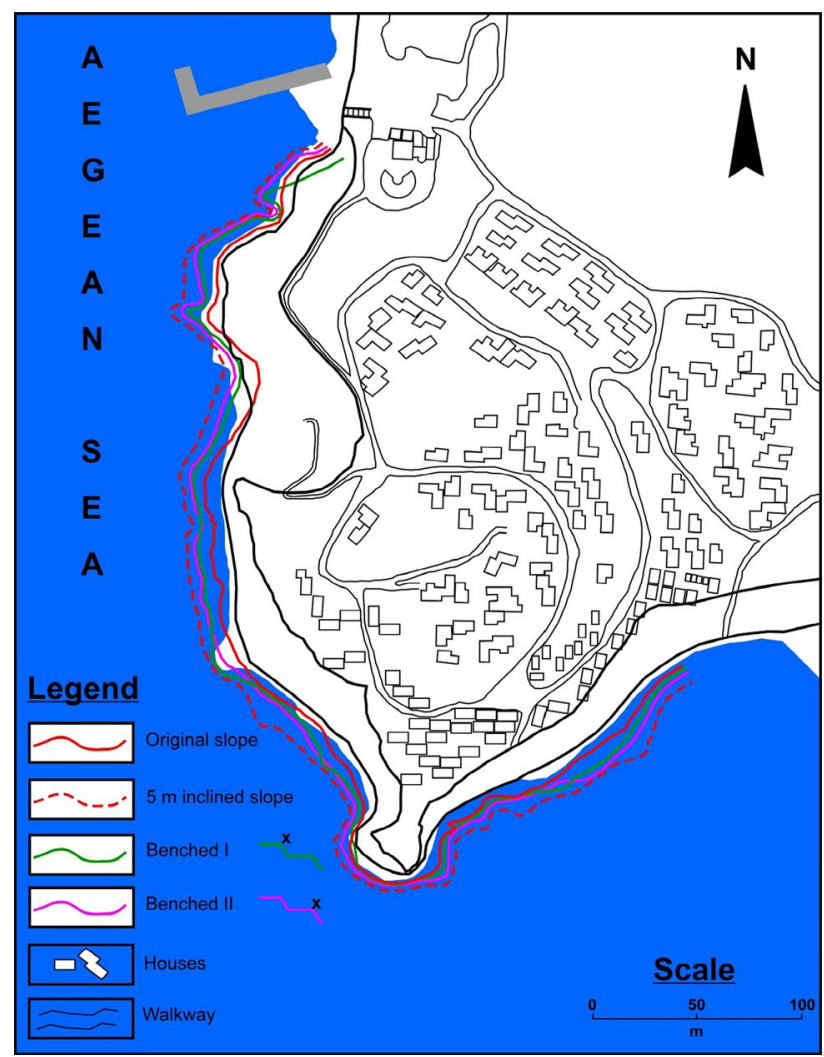

Fig. 12 Map showing rockfall end points obtained from 2-D analyses

the coast. Based on this, the profile of the existing slope must be preferred over the inclined and benched slopes. The maximum bouncing height is $5.75 \mathrm{~m}$ at the middle of profile 33 and the bouncing height significantly decreases near the coast. Therefore, a protective wall made of natural local stones should be considered at this site.

3-D analyses were performed using rotomap (Scioldo 1991) software for the original slope case only, due to the fact that slope flattening with or without a bench is not considered to be safe or feasible in this area. The Rotomap is a three-dimensional software that is used for rockfall analysis and for the design of protective systems. Simulating a large number of rockfalls and from the distribution of their average and maximum kinetic energies, it identifies the most effective places for the positioning of protective systems (GeoSoft 2005).

The first phase is a geometrical reconstruction of the slope. After definition of the topographic surface, geological and geomorphological data collections are necessary. The rockfall parameters used in the model are selected on the basis of the field conditions (Table 3). Stop point, average energy, maximum energy, minimum travel time, maximum height and volume are calculated.
Table 3 The rockfall parameters used in the 3-D analyses

\begin{tabular}{ll}
\hline Parameters & Value \\
\hline Flying limit angle $\left(^{\circ}\right)$ & 9 \\
Colliding limit angle $\left(^{\circ}\right)$ & 9 \\
Bouncing limit angle $\left(^{\circ}\right)$ & 9 \\
Number of starting points & 20 \\
Number of initial velocities & 10 \\
Minimum initial velocity $(\mathrm{m} / \mathrm{s})$ & 0.5 \\
Maximum initial velocity $(\mathrm{m} / \mathrm{s})$ & 1.5 \\
Number of initial directions & 5 \\
Maximum angular deviation $\left({ }^{\circ}\right)$ & 40 \\
Boulder mass $(t)$ & 0.083 \\
Normal coefficient of restitution $\left(R_{\mathrm{n}}\right)$ & 0.28 and 0.30 \\
Tangential coefficient of restitution $\left(R_{\mathrm{t}}\right)$ & 0.72 and 0.64 \\
Friction coefficient of boulders & 0.5 \\
\hline
\end{tabular}

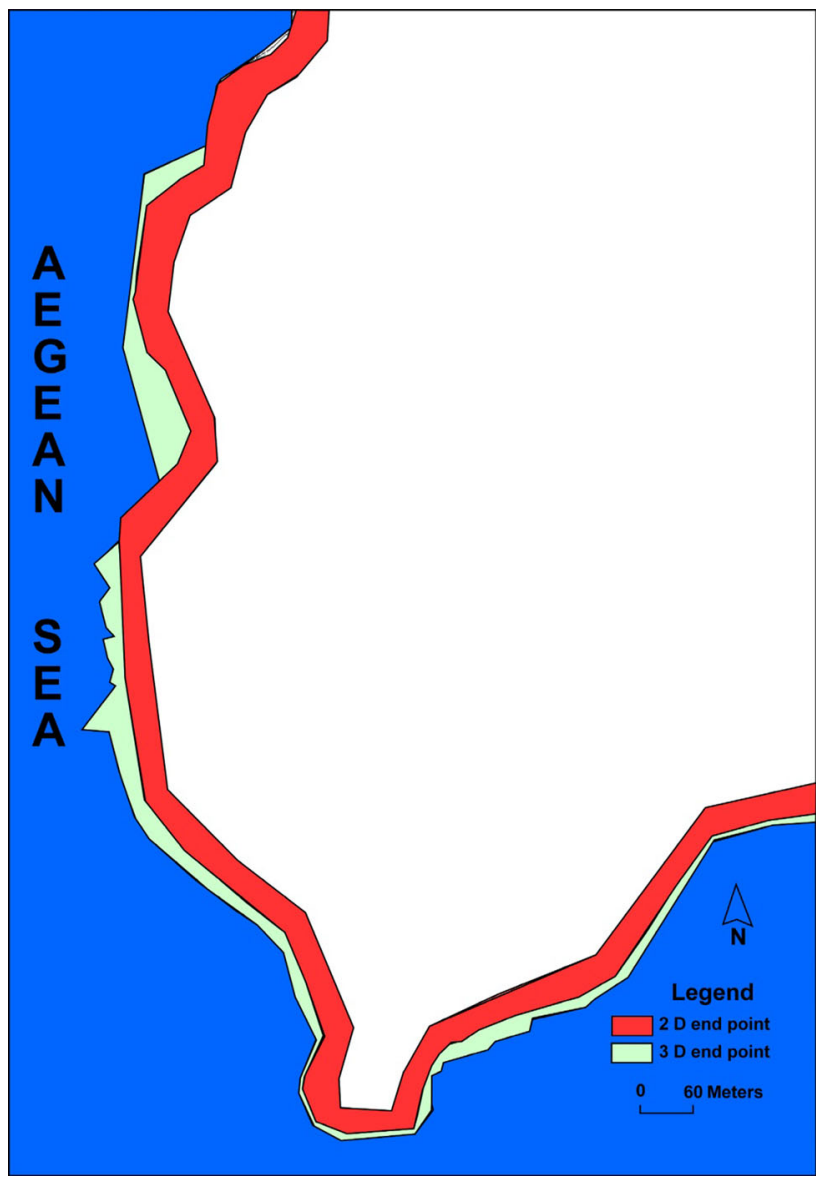

Fig. 13 The end point boundaries of 2D and 3D analysis for original slopes

The run-out distances obtained from 2-D and 3-D analyses for the original slope case show that there are some differences between the end points (Fig. 13) and bounce height values. According to the field observations and field 
Table 4 The input parameters used in the rockfall models

\begin{tabular}{ll}
\hline 2-D & 3 -D \\
\hline Total number of fallen blocks & Flying limit angle $\left(^{\circ}\right)$ \\
Friction angle $\left({ }^{\circ}\right)$ & Colliding limit angle $\left(^{\circ}\right)$ \\
Slope roughness & Bouncing limit angle $\left(^{\circ}\right)$ \\
Block weight $(\mathrm{kg})$ & Number of starting points \\
Initial velocity $(\mathrm{m} / \mathrm{s})$ & Number of initial velocities \\
Minimum velocity cut-off $(\mathrm{m} / \mathrm{s})$ & Minimum initial velocity $(\mathrm{m} / \mathrm{s})$ \\
Number of throws & Maximum initial velocity $(\mathrm{m} / \mathrm{s})$ \\
Sampling interval & Number of initial directions \\
$R_{\mathrm{n}}$ & Maximum angular deviation $\left({ }^{\circ}\right)$ \\
$R_{\mathrm{t}}$ & Maximum energy absorption capacity $(\mathrm{kJ})$ \\
& Boulder mass $(t)$ \\
& Height of the nets $(\mathrm{m})$ \\
& Starting angle $\left(^{\circ}\right)$ \\
& Free-fall height $(\mathrm{m})$ \\
& $R_{\mathrm{n}}$ \\
& $R_{\mathrm{t}}$ \\
& Friction coefficient \\
\hline
\end{tabular}

tests along profile 13 and 39, the 2-D model yields more realistic results. In the $3-\mathrm{D}$ model, the stop points of the 43 locations (Fig. 8) are farther from the coast than in the 2-D model. This can be attributed to three main parameters, namely slope geometry, the algorithm of the software, and the input parameters used.

Slope geometry is important in terms of the direction and movement of the rocks. Small variability in slope geometry makes accurate prediction extremely difficult because small changes in the slope geometry may cause major differences in the results. For the 2-D model, the trajectory and slope are assumed to be a straight profile. The inclination of the slope and the surface roughness define the velocity of the rocks and movement type (rolling, bouncing or falling). In the 3-D model, the trajectory is not a straight profile. RocFall (Rocscience 2004b) is the software used in 2-D modeling to calculate the rock movement with particle analysis. The particle analysis can be divided into three main parts: the particle algorithm, the projectile algorithm, and the sliding algorithm. The validation of all simulation parameters and preparation of initial conditions are done by the particle algorithm. In the projectile algorithm, the rock has a velocity. To calculate the movement of the rocks, the sliding algorithm is used. Sliding of the rocks can occur at any part of the slope. For the purpose of the sliding algorithm, the slope segment or barrier that the rock slides on consists of a single straight profile segment that has the properties of slope angle $(\Theta)$ and friction angle $(\Phi)$ (Stevens 1998). For 3-D modeling, different algorithms are used. A comparison of the input parameters used in the programs is given in Table 4. These differences produce different results for the end point and bounce height values. Different input parameters also cause changes in the results.

\section{General evaluations}

As revealed by the rockfall analyses, the blocks falling from the cliffs in the study area can be dangerous, particularly if the end points are considered. In common engineering practice, rock blocks with a falling potential are removed at first. In a similar way, all rocks having the potential to fall as controlled by fracture must also be removed in the study area. The intact fallen blocks can be used in building a protection wall. After opening the area for public use, checks must be periodically performed at the end of each winter and the blocks that show a tendency to fall must be removed.

In the study area, there is a surface drainage line on the upper part of the cliffs but some deficiencies were observed in the surface drainage lines at some locations. Additionally, the drainage line turns with a right angle (Fig. 14) in the north of the study area (near profile 1 in Fig. 8) which renders it unsuitable for draining water. For these two reasons, new drain lines (top width $=50 \mathrm{~cm}$, base width $=30$, depth $=40 \mathrm{~cm}$ ) must be built (Fig. 15) and the formers ones should be removed. In this way, the drainage lines, which must always be kept clear, will prevent the flow of rainwater into the cliffs.

The study area is quite green in comparison to its vicinity. Sliding and rockfall problems do not occur in those areas where a shrub kind of vegetation is very dense. For this reason, the greening of the poorly vegetated areas will 


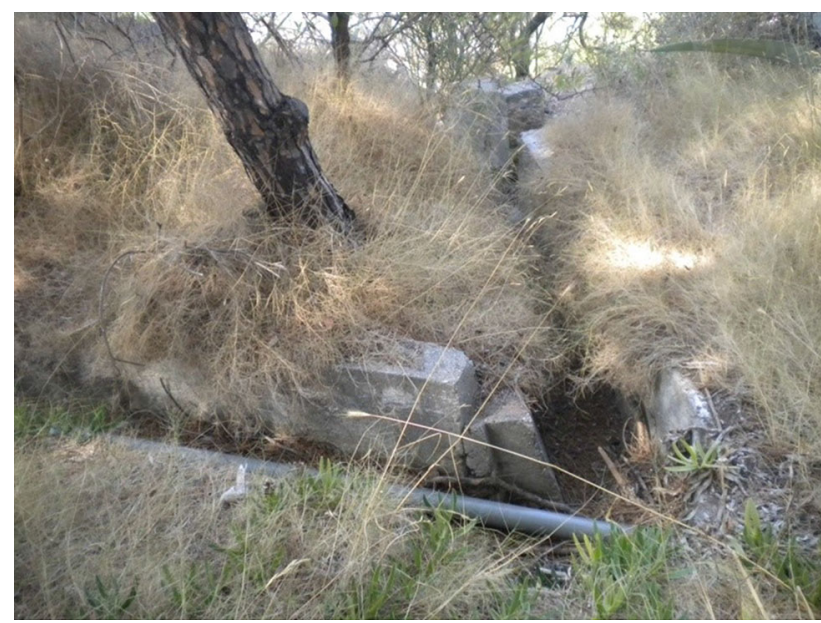

Fig. 14 Improper installation of the old surface drainage line

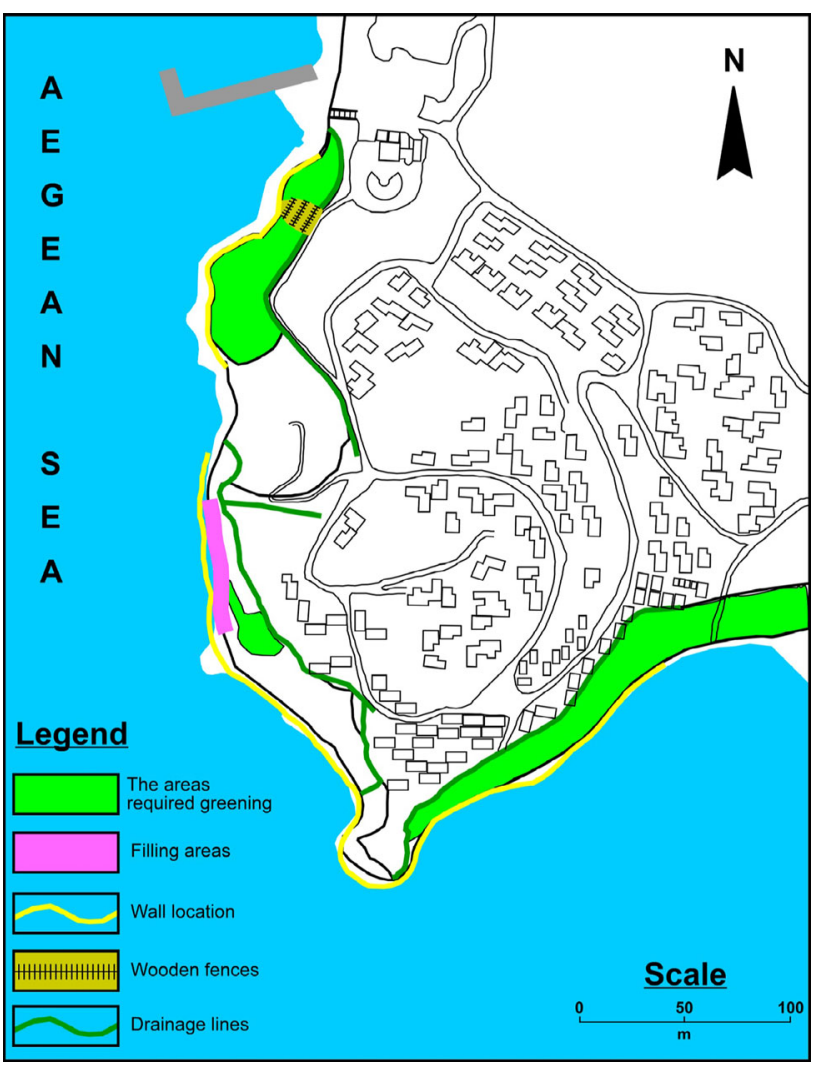

Fig. 15 Proposed remediation measures in the study area

not only improve the surrounding beauty but also reduce geological hazards (sliding, erosion, rockfall, etc.). Greening as recommended in Fig. 15 must be planned as soon as possible.

The rock units consisting of alternating sandstone-claystone-marl between profile 13 and 23 in Fig. 8 have been carved by wave action (Fig. 16). Small-scale collapses have occurred in the areas that have large caverns. Because these

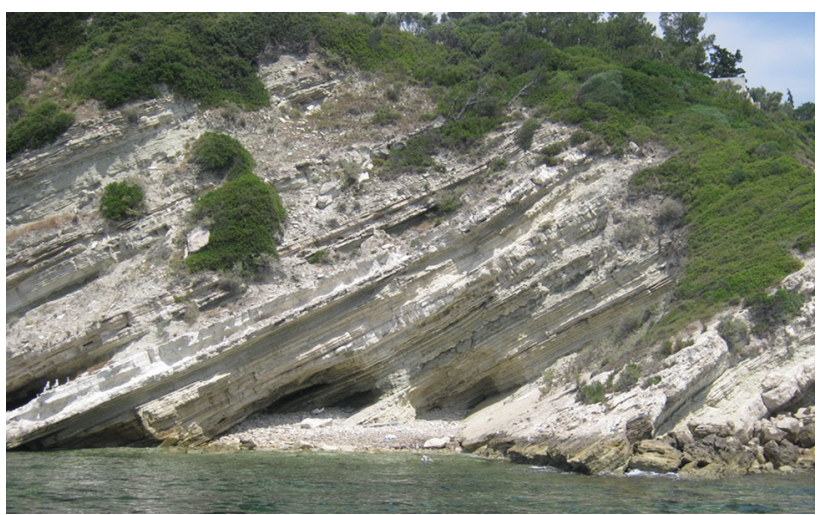

Fig. 16 The rock units carved by wave action

caverns are potentially dangerous, they must be filled fully (Fig. 15) and as early as possible with natural stones.

According to the rockfall analyses of the study area, where rockfall occurs many blocks may reach the coast. This situation would be dangerous for tourists on the coast. The evaluation was carried out by considering the bounce heights of the rock blocks, and the nearest points to the coast where the energy of the block and bounce height attenuate were defined. The locations of optimal wall points (Fig. 15) were defined using this approach. Taking the environment into consideration, intact rocks found around the study area can be used to build the protective wall. It is proposed that the wall height for the whole area should be $1.5 \mathrm{~m}$. Energy absorbers such as gravel should be installed, ensuring they have a thickness of $\sim 30 \mathrm{~cm}$; these should be positioned at the back of the wall to attenuate the energy of blocks and decrease the bounce height. Provided the fallen material collecting behind the wall is removed every year, the wall is expected to function for many years. This wall will reduce the danger from rockfalls and minimize the undercutting formed at the coast. Vegetation can be applied to this wall, eventually covering the whole wall.

The slope in the north of the study area between profile 3 and 4 in Fig. 8 has the character of a soft soil rather than rock (Fig. 15). Here, soil erosion occurs occasionally, and densely spaced iron rods have been placed to prevent the erosion. This approach prevented the erosion to some extent but it has not been entirely effective because of the limited application area. Instead of iron rods, small terracing, wooden rods and deep-rooted vegetations should be used.

\section{Conclusions and recommendations}

This study aimed to investigate the slope instability problems of a touristic costal area and to mitigate the geological hazards by recommending solutions that were nature- 
friendly and accorded with the appearance of the slopes. The study area which will soon be open to tourism has steep and high cliffs near the coast. Geological field studies have shown that the flysch exists in the study area. It contains bedding plane and mainly two joint sets as major discontinuities. Laboratory studies show that the rock units have a moderate unit weight and porosity as well as low water absorption and point load strength values. The study reveals that rockfall is the main geo-hazard. Both 2-D and 3 -D rockfall analyses indicate that many falling blocks may reach the shore and this situation would be dangerous for people in that location. To protect the tourists from these geological hazards, block removal, drainage, greening, cavern-filling, protective wall building and erosion prevention with small terracing, wooden rods and deep-rooted vegetations are suggested.

Acknowledgments The authors gratefully acknowledge the Diana Tourism Company and its employees for their helps and supports throughout the field works. The authors thank the anonymous reviewers for their constructive comments. The authors would like to thank Dr. Margaret Sonmez for comments on the use of language.

\section{References}

Abramson LW, Lee TS, Sharma S, Boyce GM (2002) Slope stability and stabilization methods, 2nd edn. Wiley, New York, p 712

Agliardi F, Crosta GB (2003) High resolution three-dimensional numerical modelling of rockfalls. Int $\mathrm{J}$ Rock Mech Min Sci 40:455-471

Agliardi F, Crosta GB, Frattini P (2009) Integrating rockfall risk assessment and countermeasure design by $3 \mathrm{D}$ modelling techniques. Nat Hazards Earth Syst Sci 9:1059-1073

Alejano LR, Ordonez C, Armesto J, Rivas T (2010) Assessment of the instability hazard of a granite boulder. Nat Hazards 53:77-95

Alejano LR, García-Cortés S, García-Bastante F, Martínez-Alegría R (2013) Study of a rockfall in a limy conglomerate canyon (Covarrubias, Burgos, N. Spain). Environ Earth Sci 70:2703-2717

Anon (1979) Classification of rocks and soils for engineering geological mapping. Part 1. Rock and soil materials. Bull Int Assoc Eng Geol 19:364-371

Ansari MK, Ahmad M, Singh R, Singh TN (2014) Rockfall hazard assessment at Ajanta Cave, Aurangabad, Maharashtra, India. Arab J Geosci 7(5):1773-1780

Azzoni A, Barbera LG, Zaninetti A (1995) Analysis and prediction of rockfalls using a mathematical model. Int J Rock Mech Min Sci Geotech Abstr 32:709-724

Binal A, Ercanoğlu M (2010) Assessment of rockfall potential in the Kula (Manisa, Turkey) Geopark Region. Environ Earth Sci 61(7):1361-1373

Bishop AW (1955) The use of slip circle in the stability analysis of earth slopes. Geotechnique 5(1):7-17

Chen H, Chen RH, Huang T (1994) An application of an analytical model to a slope subject to rockfalls. Bull As Eng Geol 31:447-458

Choi Y, Lee JY, Lee J, Park HD (2009) Engineering geological investigation into rockfall problem: a case study of the seated seokgayeorae image carved on a rock face at the UNESCO World Heritage site in Korea. Geosci J 13(1):69-78
Corominas J, Copons R, Moya J, Vilaplana JM, Altimir J, Amigó J (2005) Quantitative assessment of the residual risk in a rockfall protected area. Landslides 2(4):343-357

Crosta GB, Agliardi F (2003) A methodology for physically based rockfall hazard assessment. Nat Hazards Earth Syst Sci 3(5):407-422

DMI (2012) Devlet Meteoroloji İşleri Genel Müdürlüğü. DMI, Turkish State Meteorological Service, Ankara, Turkey

Dorren LKA (2003) A review of rockfall mechanics and modelling approaches. Prog Phys Geogr 27:69-87

Dorren LKA, Maier B, Putters US, Seijmonsbergen AC (2004) Combining field and modelling techniques to assess rockfall dynamics on a protection forest hillslope in the European Alps. Geomorphology 57:151-167

Dorren LKA, Berger F, le Hir C, Mermin E, Tardif P (2005) Mechanisms, effects and management implications of rockfall in forests. For Ecol Manage 215(1-3):183-195

Duncan JM, Wright SG, Brandon TL (2014) Soil strength and slope stability, 2nd edn. Wiley, New York, p 317

Fell R, Corominas J, Bonnard C, Cascini L, Leroi E, Savage W (2008) Guidelines for landslide susceptibility, hazard and risk zoning for land use planning. Eng Geol 102:85-98

Fityus SG, Giacomini A, Buzzi O (2013) The significance of geology for the morphology of potentially unstable rocks. Eng Geol 162:43-52

Frattini P, Crosta G, Carrara A, Agliardi F (2008) Assessment of rockfall susceptibility by integrating statistical and physicallybased approaches. Geomorphology 94(3-4):419-437

GDDA (1996) Earthquake zoning map of Turkey. In: Earthquake research department, general directorate of disaster affairs, ministry of reconstruction and resettlement of Turkey. AFAD, Ankara

GeoSoft (2005) Isomap and rotomap 3-D surface modelling \& rockfall analysis. Torino, Italy, p 69

Giani GP (1992) Rock slope stability analysis. Balkema, Rotterdam, p 361

Guzzetti F, Crosta G, Detti R, Agliardi F (2002) STONE: a computer program for the three-dimensional simulation of rockfalls. Comput Geosci 28:1079-1093

Hoek E (2007) Practical rock engineering. Course note. https://www. rocscience.com/hoek/corner/Practical_Rock_Engineering.pdf. Accessed 1 May 2014

ISRM (1981) Rock characterization, testing and monitoring. In: International society for rock mechanics suggested methods, Pergamon Press, p 211

ISRM (1985) Suggested method for determining point load strength. Int J Rock Mech Min Sci Geomech Abstr 22:51-60

Jaboyedoff M, Dudt JP, Labiouse V (2005) An attempt to refine rockfall hazard zoning based on the kinetic energy, frequency, and fragmentation degree. Nat Hazards Earth Syst Sci 5:621-632

Kentli B, Topal T (2004) Evaluation of rock excavatability and slope stability along a segment of motorway, Pozant1, Turkey. Environ Geol 46(1):83-95

Krautblatter M, Moser M (2009) A nonlinear model coupling rockfall and rainfall intensity based on a four year measurement in a high Alpine rock wall (Reintal, German Alps). Nat Hazards Earth Syst Sci 9:1425-1432

Marzorati S, Luzi L, Amicis MD (2002) Rock falls induced by earthquakes: a statistical approach. Soil Dyn Earthq Eng 22:565-577

MTA (2002) 1/500 000 ölçekli Türkiye jeoloji haritaları. In: Denizli paftası. MTA Yayınları, Ankara

Öztekin B, Topal T, Kolat C (2006) Assessment of degradation and stability of a cut slope in limestone, Ankara-Turkey. Eng Geol 84(1-2):12-30

Paronuzzi P (2009) Rockfall-induced block propagation on a soil slope, northern Italy. Environ Geol 58(7):1451-1466 
Pfeiffer TJ, Bowen TD (1989) Computer simulation of rockfalls. Bull Assoc Eng Geol 1:135-146

Priest SD (1993) Discontinuity analysis for rock engineering. Chapman \& Hall, London

Raetzo H, Lateltin O, Bollinger D, Tripet JP (2002) Hazard assessment in Switzerland-code of practice for mass movements. Bull Eng Geol Environ 61:263-268

Ramírez-Herrera MT, Inbar M, Paulín GL (2012) One hundred years of the rock fall triggered by the 1912 Acambay earthquake, Mexico. Z Geomorphol 56(4):495-505

Ritchie AM (1963) Evaluation of rockfall and its control. Highw Res Board Rec 17:13-27

Rocscience (2004a) Slide 5.1-2D limit equilibrium slope stability analysis. In: Rocscience user's guide. Toronto, p 59

Rocscience (2004b) RockFall 4.0—scientific software-statistical analysis of rockfalls. In: Rocscience user's guide. Toronto, p 59

Rocscience (2011) RocLab 1—rock mass strength analysis using the Hoek-Brown failure criterion. In: RocLab user's guide, Toronto, p 25

Schweigl J, Ferretti C, Nössing L (2003) Geotechnical characterization and rockfall simulation of slope: a practical case study from South Tyrol (Italy). Eng Geol 67:281-296

Scioldo G (1991) Isomap and rotomap- 3D surface modelling and rockfall analysis. Geo and Soft, Torino

Shi SQ, Wang M, Peng XQ, Yang YK (2013) A new-type flexible rock-shed under the impact of rock block: initial experimental insights. Nat Hazards Earth Syst Sci 13:3329-3338

Singh PK, Wasnik AB, Kainthola A, Sazid M, Singh TN (2013) The stability of road cut cliff face along SH-121: a case study. Nat Hazards 68:497-507

Stevens WD (1998) RocFall: a tool for probabilistic analysis, design of remedial measures and prediction of rockfalls. MSc thesis, Department of Civil Engineering, University of Toronto, p 38

Straub D, Schubert M (2008) Modelling and managing uncertainty in rock-fall hazards. Georisk 2(1):1-15

Tanarro LM, Munoz J (2012) Rockfalls in the Duraton canyon, central Spain: inventory and statistical analysis. Geomorphology 169:17-29

Topal T, Akın M, Özden AU (2007) Assessment of rockfall hazard around Afyon castle, Turkey. Environ Geol 53(1):191-200

Topal T, Akın MK, Akın M (2012) Rockfall hazard analysis for an historical castle in Kastamonu (Turkey). Nat Hazards $62: 255-274$
Tunusluoğlu MC, Zorlu K (2009) Rockfall hazard assessment in a cultural and natural heritage (Ortahisar Castle, Cappadocia, Turkey). Environ Geol 56(5):963-972

Turner KA, Schuster RL (1996) Landslides: investigation and mitigation. National Academy Press, Washington D.C., p 672

Turner KA, Schuster RL (2012) Rockfall: characterization and control. Transportation Research Board of the National Academies, Washington D.C., p 658

Varnes DJ (1978) Slope movement types and processes. In: Schuster RL, Krizek RJ (eds) Special report 176: landslides: analysis and control, Transportation and road research board. National Academy of Science, Washington, pp 11-33

Volkwein A, Schellenberg K, Labiouse V, Agliardi F, Berger F, Bourrier F, Dorren LKA, Gerber W, Jaboyedo M (2011) Rockfall characterisation and structural protection-a review. Nat Hazards Earth Syst Sci 11:2617-2651

Wang X, Zhang L, Ding J, Meng Q, Iqbal J, Li L, Yang Z (2014) Comparison of rockfall susceptibility assessment at local and regional scale: a case study in the north of Beijing (China). Environ Earth Sci 72:4639-4652

Wasowski J, Gaudio VD (2000) Evaluating seismically induced mass movement hazard in Caramanico Terme (Italy). Eng Geol 58:291-311

Wick E, Baumann V, Jaboyedoff M (2010) Report on the impact of the 27 February 2010 earthquake (Chile, $M_{\mathrm{w}} 8.8$ ) on rockfalls in the Las Cuevas valley, Argentina. Nat Hazards Earth Syst Sci 10:1989-1993

Wyllie DC (2015) Rock fall engineering. CRC Press, Boca Raton, p 243

Wyllie DC, Mah CW (2004) Rock slope engineering-civil and mining, 4th edn. Spoon Press, New York, p 431

Yılmazer S, Şaroğlu F, Özgür R, Açıkgöz S, Ercan T, Gevrek İA, Yıldırım N, Aydoğdu Ö (1994) Kuşadası-Davutlar (Aydın) Arasının Jeolojisi ve Jeotermal Olanaklarının Değerlendirilmesi. Türkiye 6. Enerji Kongresi, İzmir, Teknik Oturum Tebliğleri c $1: 156-167$

Youssef AM, Pradhan B, Al-Kathery M, Bathrellos GD, Skilodimous HD (2015) Assessment of rockfall hazard at Al-Noor Mountain, Makkah city (Saudi Arabia) using spatio-temporal remote sensing data and field investigation. J Afr Earth Sci 101:309-321 